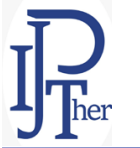

\title{
The affected factors of loss to follow up (LFU) among HIV patients with antiretroviral therapy (ART) in Dr. Sardjito General Hospital, Yogyakarta, Indonesia
}

\author{
Sri Purwaningsih ${ }^{1}$, Yanri Wijayanti Subronto ${ }^{2,3}$, Erna Kristin ${ }^{2,4 *}$
}

${ }^{1}$ Dr. Sardjito General Hospital, ${ }^{2}$ Center for Tropical Medicine, Faculty of Medicine, Public Health and Nursing, ${ }^{3}$ Department of Internal Medicine, Dr. Sardjito General Hospital/Faculty of Medicine, Public Health and Nursing, ${ }^{4}$ Department of Pharmacology and Therapy, Faculty of Medicine, Public Health and Nursing, Universitas Gadjah Mada Yogyaka, Indonesia

https://doi.org/10.22146/ijpther.481

\section{ABSTRACT}

Submitted: 19/07/2020
Accepted : 14/08/2020

\section{Keywords:}

antiretroviral therapy, HIV,

loss to follow up, CD4,

clinical stadium,
HIV infection is a global issue which is related to the increasing cases of HIV and AIDS in various countries including in Indonesia. Antiretroviral therapy (ART) that addressed for reducing the virus proliferation is not always followed by good medication adherence among patients. The ART loss to follow up (LFU) is a common problem in Indonesia. However, information concerning the affected factors of LFU among HIV patients with ART is limited. This study aimed to investigate the affected factors of LFU among HIV patients in the early two years of ART. A retrospective cohort study was conducted in Dr. Sardjito General Hospital, Yogyakarta among 369 medical records of HIV patients that met the inclusion and exclusion criteria. The inclusion criteria were HIV patients who started ART in January 2008 to December 2012, aged > 17 years with a complete medical records. The data of sociodemography and medical status patients were obtained from medical record, ART, and pharmacy register of the patients. Patient characteristics observed in this study included demographic factors such as age, sex, residence, education level, risk factors, and also medical status factors such as clinical stage, tuberculosis (TB) co-infection, functional status, and CD4 cell counts. The data were analyzed using Kaplan Meier and Cox Proportional Hazard. The results showed that patients with TB co-infection in early therapy and working functional status were significant factors of LFU $(p<0.05)$. Patients without TB co-infection were half as much protected from LFU compared to patients with TB infection (HR=0.50; 96\% CI: 0.34-0.75). It can be concluded that TB coinfection in early therapy and working fuctional status are the significant factors that influenced the LFU incidents in the two years of early therapy.

\begin{abstract}
ABSTRAK
Infeksi HIV merupakan masalah global yang berkaitan dengan meningkatnya kasus HIV dan AIDS di berbagai negara termasuk Indonesia. Pemberian terapi antiretroviral (ARV) yang ditujukan sebagai upaya untuk menekan perkembang biakan virus dalam darah tidak selalu diikuti dengan kepatuhan minum obat yang baik pada pasien. Loss to follow up (LFU) merupakan masalah yang banyak terjadi di Indonesia. Namun informasi mengenai faktor yang mempengaruhi LFU pada pasien HIV dengan terapi ARV masih terbatas. Penelitian ini dilakukan untuk mengkaji faktor faktor yang mempengaruhi terjadinya LFU pada pasien HIV dalam dua tahun pertama terapi ARV. Studi kohort retrospektif dilakukan di RSUP Dr. Sardjito, Yogyakarta terhadap 369 sampel rekam medis pasien HIV yang memenuhi kriteria inklusi dan eksklusi. Kriteria inklusi penelitian yaitu pasien HIV yang dimulai terapi ARV pada periode Januari 2008-Desember 2012, berumur $>17$ tahun dengan rekam medik yang lengkap. Data sosiodemografi dan status medis pasien diperoleh dari rekam medis pasien, register ARV dan register farmasi. Karakteristik pasien yang diamati pada penelitian ini meliputi faktor demografis seperti usia, jenis kelamin, tempat tinggal, tingkat pendidikan, faktor risiko, dan juga faktor status medis seperti stadium klinis, koinfeksi TB, status fungsional, dan nilai CD4. Analisis hasil data menggunakan Kaplan Meier dan Cox Proportional Hazard. Hasil penelitian menunjukkan bahwa pasien dengan koinfeksi TB di awal terapi dan status fungsional kerja merupakan faktor signifikan terhadap LFU ( $\mathrm{p}<0.05)$. Pasien yang tidak terinfeksi TB setengah kali lebih protektif untuk tidak terjadi LFU dibandingkan pasien yang terinfeksi TB (HR=0,50; 96\%CI: 0,34-0,75). Dapat disimpulkan koinfeksi TB pada awal terapi dan status fungsional merupakan faktor yang signifikan mempengaruhi terjadinya LFU dalam dua tahun pertama terapi ARV.
\end{abstract}




\section{INTRODUCTION}

Human immunodeficiency virus (HIV) and acquired immunodeficiency syndrome (AIDS) infection currently become the biggest health problem worldwide. ${ }^{1}$ Based on published data by joint United National program on HIVAIDS (UNAIDS), at the end of 2010, there were 34 million peoples estimated living with HIV, and 1.8 million death. ${ }^{1}$

Yogyakarta Special Provincial Health Office has reported that a cumulative number of HIV-AIDS patients of 2259 people enrolled in HIV treatment from August 2005 to December 2013, and 1852 people $(81.98 \%)$ were eligible to start ART. Of those who had started ART, 451 peoples (26.42\%) had loss to follow up (LFU). ${ }^{2,3}$ Factors that influence the occurrence of the LFU are age, ${ }^{4}$ gender, ${ }^{5}$ level of education, residence, employment, marital status, ${ }^{6}$ risk factors, CD4 cell count, clinical stage, tuberculosis (TB) co-infection and functional status. ${ }^{7}$

This study aimed to investigate the affected factors that influence the LFU among HIV patients in early two years ART. This study is useful to increase the management of HIV patients care and determine the best strategies for LFU prevention.

\section{MATERIAL AND METHODS}

\section{Subject}

This study used the retrospective cohort methods. Secondary data were collected from medical record, ART register and pharmacy register. Patients observation was carried out for two years since ART start. The inclusions criteria were adult patients aged over 17 years who start ART from January 2008 to December 2012. The selected subject were observed until incidents of drop out or ART LFU. The LFU patient were defined as patients who did not come to the clinic for three consecutive months. The observation periods were two years. Patient confidentiality was protected by not including the patient's identity and changing the patient's identity using a subject code.

\section{Procedure of study}

Data ware collected from medical records, national ART register, and pharmacy register of the patients who started ART on Januari 2008 - Desember 2012. The identities and clinical data of the patients were observed on early two years ART. The observation was conducted for the LFU patients and saw the affected factors, based on demographic characteristic or medical status. The patients criteria for analyzed were adult patients more than 17 years. The sociodemographic data were age, residence, working status, marital status, intravenous drug use (IDU) and non IDU risk factor. The clinical data were WHO clinical stadium, CD4, TB co-infection and functional status.

\section{Statistical analysis}

Kaplan Meier was used to analyzing the survival of the time used of LFU in two years observation. Cox Proportional Hazard as the univariate analysis was used to evaluate the correlation between independent and dependent variables. The multivariate analysis was performed to identify the independent and dependent variables together.

\section{RESULTS}

\section{Characteristic of subjects}

Three hundred and sixty nine eligible subjects were involved in this study. The characteristic of subjects are presented in TABLE 1. 
TABLE 1. Sociodemographic characteristic

\begin{tabular}{|c|c|c|c|}
\hline Variable & $\begin{array}{c}\text { Total } \\
(n=369)\end{array}$ & $\begin{array}{c}\text { LFU } \\
{[n=160(43.4 \%)]}\end{array}$ & $\begin{array}{c}\text { No LFU } \\
{[n=209(56.6 \%)]}\end{array}$ \\
\hline \multicolumn{4}{|l|}{ Age (y.o.) } \\
\hline - $18-29$ & $147(39.8 \%)$ & $69(43.1 \%)$ & $78(37.3 \%)$ \\
\hline - $\quad 30-39$ & $128(34.7 \%)$ & $56(35.0 \%)$ & $72(34.5 \%)$ \\
\hline - $\quad \geq 40$ & $93(25.2 \%)$ & $34(21.3 \%)$ & $59(28.2 \%)$ \\
\hline - Unknown & $1(0.3 \%)$ & $1(0.6 \%)$ & $0(0 \%)$ \\
\hline \multicolumn{4}{|l|}{ Sex } \\
\hline - Male & $237(64.2 \%)$ & $106(66.3 \%)$ & $131(62.6 \%)$ \\
\hline - Female & $132(35.7 \%)$ & $54(33.7 \%)$ & $78(37.4 \%)$ \\
\hline \multicolumn{4}{|l|}{ Residence } \\
\hline - Bantul & $65(17.6 \%)$ & $32(20.0 \%)$ & $33(15.8 \%)$ \\
\hline - Sleman & $71(19.3 \%)$ & $33(20.6 \%)$ & $38(18.2 \%)$ \\
\hline - Gunungkidul & $18(4.9 \%)$ & $6(3.8 \%)$ & $12(5.7 \%)$ \\
\hline - Kulonprogo & $9(2.4 \%)$ & $4(2.5 \%)$ & $5(2.4 \%)$ \\
\hline - Yogyakarta & $113(30.6 \%)$ & $45(28.1 \%)$ & $68(32.6 \%)$ \\
\hline - Out of Yogyakarta & $87(23.6 \%$ & $37(23.1 \%)$ & $50(23.9 \%)$ \\
\hline - Unknown & $6(1.6 \%)$ & $3(1.9 \%)$ & $3(1.4 \%)$ \\
\hline \multicolumn{4}{|l|}{ Working status } \\
\hline - Working & $183(49.6 \%)$ & $79(49.4 \%)$ & $104(49.8 \%)$ \\
\hline - Not working & $166(45.0 \%)$ & $67(41.9 \%)$ & $99(47.4 \%)$ \\
\hline - Unknown & $20(5.4 \%)$ & $14(8.7 \%)$ & $6(2.8 \%)$ \\
\hline \multicolumn{4}{|l|}{ Education } \\
\hline - Low & $94(25.5 \%)$ & $34(21.3 \%)$ & $60(28.7 \%)$ \\
\hline - High & $268(72.6 \%)$ & $121(75.6 \%)$ & $147(70.3 \%)$ \\
\hline - Unknown & $7(1.9 \%)$ & $5(3.1 \%)$ & $2(1.0 \%)$ \\
\hline \multicolumn{4}{|l|}{ Marital status } \\
\hline - Not Married & $109(29.5 \%)$ & $49(30.6 \%)$ & $60(28.7 \%)$ \\
\hline - Married & 219 (59.4\%) & $96(60.0 \%)$ & $123(58.8 \%)$ \\
\hline - Divorced & 37 ( $10.0 \%)$ & $12(7.5 \%)$ & $25(12.0 \%)$ \\
\hline $\begin{array}{l}\text { Unknown } \\
\text { - Risk factor }\end{array}$ & $4(1.1 \%)$ & $3(1.9 \%)$ & $1(0.5 \%)$ \\
\hline • IDU & $86(23.3 \%)$ & $37(23.1 \%)$ & $49(23.4 \%)$ \\
\hline - Non-IDU & $283(76.7 \%)$ & $123(76.9 \%)$ & $160(76.6 \%)$ \\
\hline
\end{tabular}

From 369 patients who started ART on period of 2008-2012, 160 patients (43.4\%) were LFU and 209 patients (56.6\%) still on treatment. Of 369 patients who met the study criteria, 147 (39.8\%) were aged 18-29 y.o. and 113 resided in Yogyakarta (30.6 \%), 183 (49.6\%) worked as employee and 268 (72.6\%) were having high educational background, 219 patients (59.4\%) reported that they were married, and 283 patients stated that they were non IDUs (76.9\%).

The patients distribution based on sociodemographic characteristic with LFU incidents on TABLE 1 showed that the highest group of age was 18-29 y.o. $(43.1 \%)$ and the highest group of sex was men (66.3\%). Patients with high education level were the highest group of LFU (75.6\%). Patients with non IDU risk factors were the highest group of LFU (76.9\%). 
TABLE 2. Medical status characteristic

\begin{tabular}{|c|c|c|c|}
\hline Variable & $\begin{array}{c}\text { Total } \\
(n=369)\end{array}$ & $\begin{array}{c}\text { LFU } \\
{[n=160(43.4 \%)]}\end{array}$ & $\begin{array}{c}\text { No LFU } \\
{[n=209(56.6 \%)]}\end{array}$ \\
\hline \multicolumn{4}{|c|}{ CD4 cell count (cell//mm³) } \\
\hline$\bullet \leq 50$ & $177(48.0 \%)$ & $76(47.5 \%)$ & $101(48.3 \%)$ \\
\hline - 51-199 & $127(34.4 \%)$ & $54(33.7 \%)$ & $73(34.9 \%)$ \\
\hline$\bullet \geq 200$ & $57(15.4 \%)$ & $27(16.9 \%)$ & $30(14.4 \%)$ \\
\hline • Unknown & $8(2.2 \%)$ & $3(1.9 \%)$ & $5(2.4 \%)$ \\
\hline \multicolumn{4}{|c|}{ WHO clinical status } \\
\hline • Low (I/II) & $181(49.1 \%)$ & $75(46.9 \%)$ & $106(50.7 \%)$ \\
\hline • High (III/IV) & $179(48.5 \%)$ & $79(49.4 \%)$ & $100(47.9 \%)$ \\
\hline • Unknown & $9(2.4 \%)$ & $6(3.7 \%)$ & $3(1.4 \%)$ \\
\hline \multicolumn{4}{|l|}{ TB-coinfection } \\
\hline • $\mathrm{TB}$ & 73 (19.7) & $41(25.6 \%)$ & $32(15.3 \%)$ \\
\hline - No TB & $274(74.3 \%)$ & $102(63.8 \%)$ & $172(82.3 \%)$ \\
\hline • Unknown & $22(6.0)$ & $17(10.6 \%)$ & $5(2.4 \%)$ \\
\hline \multicolumn{4}{|l|}{ Functional status } \\
\hline • Ambulatory & $124(33.6 \%)$ & $47(29.4 \%)$ & $77(36.8 \%)$ \\
\hline - Working & $235(63.7 \%)$ & $108(67.5 \%)$ & $127(60.8 \%)$ \\
\hline - Unknown & $10(2.7 \%)$ & $5(3.1 \%)$ & $(1.4 \%)$ \\
\hline
\end{tabular}

The distribution based on medical status characteristics from TABLE 2 showed that most of the patients were on end-clinical stadium when ART started with highest number of LFU incidents (49.4\%). Patients without TB coinfection when ART started were highest LFU group (63.8\%) and patients with working functional status were the highest incidents of LFU (67.5\%). CD4 cell count numbers $\leq 50 \mathrm{sel} / \mathrm{mm}^{3}(47.5 \%)$, on late clinical stadium (49.4\%), and working functional status (67.5\%)were the characteristics of patients with LFU.

TABLE 3. Factor associated with LFU within 24 months

\begin{tabular}{|c|c|c|}
\hline \multirow{2}{*}{ Variable } & \multicolumn{2}{|c|}{ Multivariate analysis } \\
\hline & HR $(95 \%$ CI) & $\mathrm{p}$ \\
\hline \multicolumn{3}{|l|}{ Age (y.o.) } \\
\hline • $18-29$ & 1 & \\
\hline • 30-39 & $0.99(0.68-1.43)$ & 0.9500 \\
\hline$\bullet \geq 40$ & $0.68(0.42-1.11)$ & 0.1200 \\
\hline \multicolumn{3}{|l|}{ Education } \\
\hline - Low & 1 & \\
\hline - High & $0.71(0.48-1.06)$ & 0.0960 \\
\hline \multicolumn{3}{|l|}{ TB-coinfection } \\
\hline - $\mathrm{TB}$ & 1 & \\
\hline - No TB & $-0.50(0.34-0.75)$ & 0.0010 \\
\hline \multicolumn{3}{|c|}{ Functional status } \\
\hline - Ambulatory & 1 & \\
\hline • Working & $1.73(1.17-2.56)$ & 0.0060 \\
\hline
\end{tabular}


TABLE 3 showed the multivariat analysis result. The variables that significantly increase LFU incidents were TB coinfection and working functional status. Patients who started ART with functional status and without TB coinfection were more protective for
LFU risks. Patients with TB coinfection had half more risk of LFU incidents than patients without TB coinfection (95\%CI: 0.34-0.75). Patients with working functional status had 1.73 more risk of LFU when ART started than ambulatories patients (95\%CI: 1.17-2.56).

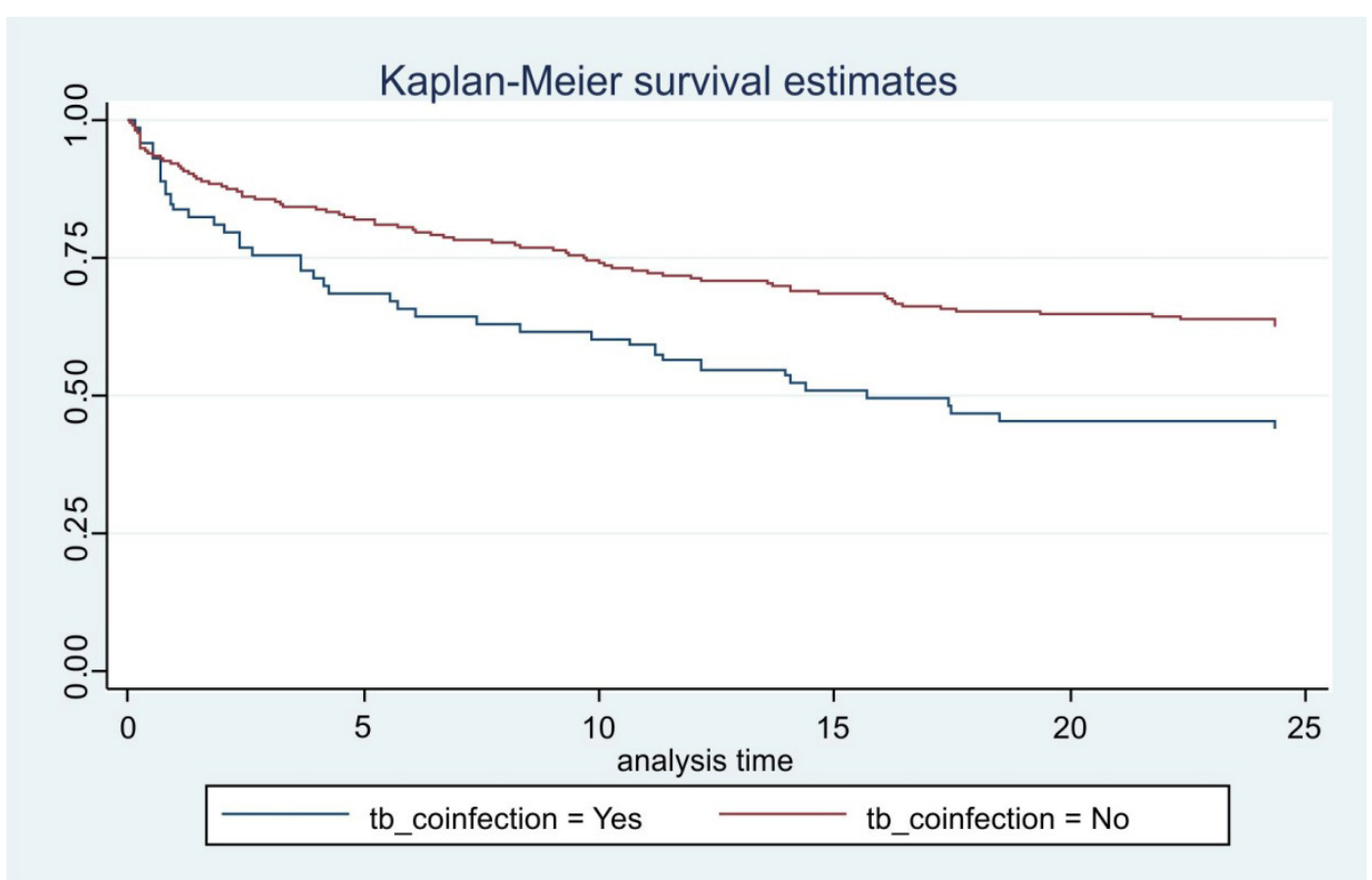

FIGURE 1. Graphic of Tb coinfection survival time

FIGURE 1 showed TB co-infection Kaplan Meier Survival graphic. The patients who started ART with TB infection had a greater risk of LFU incidents compared to patients without TB infection. The number of LFU incidents on patients with TB infection in early ART within 2 years were 48.1 per 100 peoples-years. The highest number of LFU occured in early 6 months after ART started which was 92.9 per 100 peoples-years.

\section{DISCUSSION}

The study result from restrospective kohort have been identified at the end of LFU observation were $16.41 \%^{8,9}$ Observation total time were 6119.2 person time with death rate 2.61 by 100 peoples by month.

World Health Organization defines
LFU as patients who has not been seen at the clinic for at least 90 days (three months) after the last missed appointment. ${ }^{10}$ Some factors can influence patient retention in HIV care such as site specific factor, health system weaknesses, financial barriers, patient/caregiver characteristics, and community factors. ${ }^{11}$

From the bivariate analysis, we had variables that have significant relation with LFU incident which is TB coinfection and working functional status. Patients who started ART with TB coinfection had more risks to LFU incidents (95\% CI: 0.34-075). Patients with working functional status when ART started had 1.73 more risk of LFU than ambulatories patients (95\%CI: 1.17-2.56).

From the medical records distribution we found patients who started ART on late WHO clinical stadium, CD4 numbers 
$<50 \mathrm{cell} / \mathrm{mm}^{3}$, working functional status and non IDUs risk factor, did not have significant relation with LFU incidents. These were not appropriate with the study in Zambia and Swiss which had different results. ${ }^{8}$ The factors related to the LFU incidents were III/IV Clinical Stadium and CD4 cell count numbers $<100$ cell $/ \mathrm{mm}^{3}{ }^{8}$ Study in Zambia had different results with Swiss, which LFU incidents were found among patients with high CD4 numbers in the early treatment and early clinical stadium. ${ }^{8}$

HIV patients from IDUs risk factor were having stigma as a bad temper and undiscipline peoples..$^{12}$ Bivariate analysis showed that IDUs risk factor does not have significant relation with LFU incidents ( $p>0.985)$, while the TB coinfection were have significant relation $(p<0.05)$ to increase the LFU incidents among HIV patients with ART for two years.

The high death risk among patients with TB coinfection was related to the bad immune repair process on ART. Age over 40 y.o. were having risk of chronic diseases that could cause death. ${ }^{13,14} \mathrm{Bad}$ response on ART, rapid development of chronic disease and complication disease such as cancer dan cadiovascular diseases were combined effect from aging, HIV infection and ART effects that could increase death risks because of bad immune recovery on ART.8,15 These different results showed that there were different patient responses on ART because of the different characteristic and cultural population di every country. ${ }^{16}$ The highest number of LFU occured in early 6 months after ART started were 92.9 per 100 peoples-years.

This study has limitations such as the loss of information related to patient data due to incomplete data from the ARV register, medical records, and pharmacy register and differences in numbering of patient's identities in the ARV register, medical records, and pharmacy register.

\section{CONCLUSION}

Tuberculosis co-infection in early ART significantly increases the risk of
LFU among HIV patients in early two years ART, where the highest incidents occurs on the first sixth months. In this study, working functional status also influences the LFU incidents. Emphasis needs to be placed on improving followup and documentation of patients care on HIV treatments. Community-based approach such as peer support groups (kelompok pendukung sebaya/KDS) and health information system integration such as SMS reminder designed for atrisk population (patients with TB confection and working functional status) can be further studied to reduce LFU incidents.

\section{ACKNOWLEDGEMENTS}

The author would like to thanks Dr. Ning Rintiswati and Dr. Elsa Herdiana for the full support in this study.

\section{REFERENCES}

1. UNAIDS. UNAIDS Worlds AIDS Day Report 2011, Joint United Nations Programme on HIV/AIDS.2011.

2. Dinas Kesehatan Prov DIY. 2014. Laporan bulanan HIV tahun 2014.

3. Kementrian Kesehatan Republik Indonesia (Kemenkes RI). Laporan Perkembangan Situasi HIV dan AIDS di Indonesia triwulan 3 September Tahun 2013. Jakarta: Direktorat Jenderal Pengendalian Penyakit dan Penyehatan Lingkungan, 2013.

4. Blevins M, Bilhete FR, Vaz LME, Shepherd BE, Audet CM, Vermund $\mathrm{SH}$, et al. Two-year death and loss to follow-up outcomes by source of referral to HIV care for HIV-infected. AIDS Res Hum Retroviruses 2015; 31(2):198-207.

https://doi.org/10.1089/aid.2014.0007

5. Alvarez-uria G, Naik PK, Pakam R, Midde M. Factors associated with attrition, mortality, and loss to follow up after antiretroviral therapy initiation: data from an HIV cohort study in India. Glob Health Action 2013; 1:1-8.

https://doi.org/10.3402/gha.v6i0.21682

6. Bekolo CE, Webster J, Batenganya M, 
Sume GE, Kollo B. Trends in mortality and loss to follow-up in HIV care at the Nkongsamba Regional Hospital, Cameroon. BMC Res Notes 2013; 6(1):1-16.

https://doi.org/10.1186/1756-0500-6-512

7. Mugisha V, Teasdale CA, Wang C, Lahuerta M, Biribonwoha HN, Tayebwa E, et al. Determinants of mortality and loss to follow-up among adults enrolled in HIV care services in Rwanda. PloS One 2014; 9(1):e85774.

https://doi.org/10.1371/journal. pone.0085774

8. Schöni-Affolterr F, Keiser O, Mwango A, Stringer J, Mulenga BBL, et al. Estimating loss to followup in HIV-infected patients on antiretroviral therapy: the effect of the competing risk of death in Zambia and Switzerland. Plos One 2011; 5(5):e10584.

https://doi.org/10.1371/journal. pone.0027919

9. Gerver SM, Chadborn TR, Ibrahim F, Vatsa B, Delpech VC, Easterbrook PJ, et al. High rate off loss to clinical follow up among African HIV infected patients attending a London clinic; a retrospectif analysis of clinical cohort. J Int AIDS Soc 2010; 13-29.

https://doi.org/10.1186/1758-2652-13-29

10. World Health Organization. Consolidated guidelines on personcentred HIV patient monitoring and case surveillance. Geneva: World Health Organization, 2017.

11. World Health Organization. Retention in HIV programmes: defining the challenges and identifying solutions: meeting report, 13-15 September 2011. Geneva: World Health Organization, 2012.

12. Surilena, Minawati, Rensa, Isadora, Suryani E, Hartono TS. Kepatuhan ODHA pengguna NAPZA suntik dengan atau tanpa ko-infeksi TB/Hepatitis virus dalam terapi antiretroviral dan metadon. CDK230 2015; 42(7):487-92.

13. Departemen Kesehatan Republik Indonesia. Pedoman nasional perawatan dukungan dan pengobatan bagi ODHA. Jakarta: Direktorat Jendral P2M \& PL, 2003.

14. Hambisa MT, Ali A, Dessie Y. Determinanas of mortality among HIV positives after initiating antiretroviaral therapy in Western Ethiopia: A hospital-based retrospecif cohort study. ISRN AIDS 2013; 2013:491601.

https://doi.org/10.1155/2013/491601

15. Nansera D, Bajunirwe F, Elyanu P, Asiimwe C, Amanyire G, Graziano F. Mortalty and lossto follow up amnog tuberculosis and HIV co-infection patients in rulal South Western Uganda. Inter J Tuberc Lung Dis 2012; 16(10):1371-76. https://doi.org/10.5588/ijtld.11.0589

16. Marrone G, Thorson A, Lukhwaro A, Ilako F, Ekstro AM. Longterm adherence to antiretroviral treatment and program drop-out in a high-risk urban setting in SubSaharan Africa : a prospective cohort study. PloS One 2010; 5(10):e13613. https://doi.org:10.1371/journal. pone.0013613 